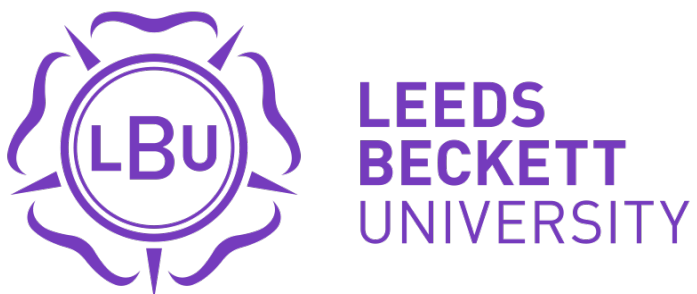

Citation:

Gerodetti, N (2008) Review essay: new writings on love, sex and kisses. Journal of Contemporary History, 43 (2). 343 - 351. ISSN 1461-7250 DOI: https://doi.org/10.1177/0022009408089036

Link to Leeds Beckett Repository record:

https://eprints.leedsbeckett.ac.uk/id/eprint/1331/

Document Version:

Article (Accepted Version)

The aim of the Leeds Beckett Repository is to provide open access to our research, as required by funder policies and permitted by publishers and copyright law.

The Leeds Beckett repository holds a wide range of publications, each of which has been checked for copyright and the relevant embargo period has been applied by the Research Services team.

We operate on a standard take-down policy. If you are the author or publisher of an output and you would like it removed from the repository, please contact us and we will investigate on a case-by-case basis.

Each thesis in the repository has been cleared where necessary by the author for third party copyright. If you would like a thesis to be removed from the repository or believe there is an issue with copyright, please contact us on openaccess@leedsbeckett.ac.uk and we will investigate on a case-by-case basis. 


\section{Review Essay \\ New Writings on Love, Sex and Kisses}

Natalia Gerodetti

Karen Harvey (ed)(2005) The Kiss in History. Manchester: Manchester University Press.

Nils Ringdal (2004) Love for Sale: A Global History of Prostitution. London: Atlantic Books.

Marcus Collins (2003) Modern Love: An Intimate History of Men and Women in Twentieth Century Britain. London: Atlantic Books.

Lesley Hall (2005) Outspoken Women: An Anthology of Women's Writing on Sex, 1870-1969. London and New York: Routledge.

The titles of these four books suggest that they are all an undertaking in and contribution to histories of sexuality. And although they are indeed, each in a rather different way, they also and importantly collectively raise questions regarding the boundaries of history and ask questions about ways of knowing and the production of knowledge: for all these books present the reader with accounts that are at the intersections between social and cultural history.

An overt claim to being cultural history is The Kiss in History which charts the kiss in European contexts between 1500 and 1918. The book contains an interesting collection of chapters bearing on cultural practices of the kiss which, far from being merely connotated with sexuality or intimacy, carry a plethora of cultural, social and political meanings which the chapters discuss in a succinct manner. The kiss as an act or a symbol or a practice provides an interesting focus to examine cultural history from a particular point leaving the reader rather than knowing what the kiss is with the incentive to ask: the kiss of what? The introduction provides the theoretical framework of a cultural history while the chapters substantively apply such a methodology to particular kisses in history. Being the proceedings of a conference the book works well and brings together people working in the area of the history of gender, sexuality, consumption, politeness, political life, witch persecutions, death, religion and magic, family, illness as well as drowning and resuscitation.

Whilst previous histories of the kiss have approached it in different categories ${ }^{1}$ such as kisses of love, affection, peace, respect and friendship this book seeks to take a single kiss as an index to the past thereby not producing a history of the kiss but a book about the kiss in history using a wide range of evidence such as canonical religious texts, popular prints, court depositions, periodicals, diaries and poetry. The focus on the kiss as a gesture thus brings together what may appear to be disparate chronological periods or practices as well as different histories.

The book thus considers kisses in history between 1500 and 1918 although somewhat oddly, the focus the kiss as an act or a gesture also somewhat contradictory is productive of kisses in histories that do not have actors. Nevertheless, the book begins

\footnotetext{
${ }^{1}$ See for instance, C.C. Bombaugh (1876) The Literature of Kissing, Gleaned from History, Poetry, Fiction and Anecdote, or C. Nyrop (1901) The Kiss and its History.
} 
with an introduction by Harvey who concisely sets out a theoretical framework for the following chapters by making a case for the similarities between cultural history and new historicism. She places cultural history's vision of culture in a tradition to the French Annales School and in the approach of historians of mentalities. In doing so, Harvey distinguishes the aim of new historicists, that is, an understanding of poetic, cultural and aesthetic objects through the social functions they perform, from the aim of cultural historians who try to understand the social and cultural partly through an analysis of art or literature. Cultural history emerges as a "discipline of context" in Thompson's tradition and Harvey thus argues that the chapters in the book are not simply interested in meaning and its representation but in the practices and social workings of language.

A single kind of kiss is taken as an index to the past in each chapter, pointing to a history of gestures rather than an act. Thus, representations of what kisses signified and what they enabled people to articulate are fore grounded in the book which also contains an afterword by Keith Thomas who provides interesting thoughts on the collection of chapters. Kisses as potent markers of boundaries in the early modern period are explored in chapters on German trials where women refused to admit to the shameful act of kissing the Devil's anus during Sabbath, or the kiss of life which was rendered difficult for gentlemen due to restrictions on intimacy with one's social inferiors. The chapter on the late eighteenth century kisses-for-votes scandal, which discusses the lobbying efforts of the Duchess of Devonshire which regularly involved canvassing with kisses, equally treats the transgression of boundaries through the kissing of social inferiors. Thus, though kisses as gestures were frequently used in various social encounters they were easily transgressed by crossing the line between appropriate and inappropriate kissing which signalled a rupture in normal power relations. There was, of course, also the erotic kiss and it is the potential for ambiguity which sets the kiss apart from other gestures. Nevertheless, to claim that the kiss is more ambiguous than other gestures seems to set it apart too much. The erotic nature complicated the kiss of peace in Reformation debates whilst similar worries also impacted upon debates about resuscitation in eighteenth century England.

In her framing of the book, Harvey also outlines Elias' civilisation process yet contests the sexualisation of the kiss in a civilising narrative. Instead she argues that 1600-1800 produced the most intense and broad debate around kissing while later gestures of kissing allow us to observe discontinuity. There emerges a slight contradiction in imposing such an evolutionary paradigm if the interest is to contextualise kisses in history rather than providing a history of the kiss. Nevertheless, Harvey argues that while Elias' methodology was designed to bring a process and its a gradual transformation into view, so the case studies in the book bring the fluctuations and curves of the past into relief. The book is organised into three thematic and chronological sections, "worship and ritual", "ambiguity and transgression" and "power and intimacy". Again, this imposes order by the editor whilst the chapters' merit is to flesh out particular moments in particular places and practices and meaning of the kiss therein rather than, somewhat contradictorily, impose an overarching chronological narrative.

Boundaries frequently emerge as a frame and are explored in a chapter that focuses on the range and limits of intimate relationships and the shady ground between platonic friendship and erotic love. Platonic relationships were sexualised rendering 
'friendship without desire between men and women' difficult to imagine. This is followed by a chapter on blurred lines between social and sexual kisses in the context of politeness and manners. The social practice of kissing played a critical role in the initiation of adulterous relationships but equally notions of proper and improper sociability were also formed around kissing. "Kisses for votes" charts the story of how corruption was gendered as female in voting history as disintegrating gender and class boundaries undermined the British polity. Class and status boundaries provide the focus in a contribution of kisses in context of ill health in a mistress-governess relationship and the story of men kissing in the trenches equally allude to the intimate nature of kisses rather than sexual. The exchange of dying soldiers in the First World War thus tell a different story about the moralised expressions of intimacy between same sexed adults in the beginning twentieth century. The kiss in history provides illuminating accounts and examinations of a gesture that we take for granted.

Such critical inquiry is unfortunately absent from Ringdal's book on Love for Sale: $A$ Global History of Prostitution. The book sets out with the saying that prostitution is the world's oldest profession and has ostensibly been declared, since the Renaissance, to be universal and constituted "naturally" through gender relations. Ringdal critically departs from this self-serving generalisation and maps out the premise that the prostitute and prostitution served as symbols of sin which functioned to guarantee or stabilize (or destabilize) morality and matrimony in societies. Much of the introduction is pitched towards a historical development towards a focus on the Victorians and its development since then. Many ways interesting questions are alluded to in this first part in terms of how prostitution fits into larger conceptualisations of sexualities, male and female, its impact on and deriving from gender roles, and a juxtaposition with ideas and practices of family and reproduction. Yet while setting out such interesting premises the twenty nine chapters following only address these questions occasionally and are organised, rather than around the thread of examining discourses and practices of prostitution in the nexus to ideas about sexuality and matrimony, mostly around a chronological thread analogous to a "history of civilisations".

Having asserted that "the strength and status of the family define the status assigned to the prostitutes, as different family structures provide the men by various acceptance of extramarital sex" (p.2) which in some regions has put the family almost out of play, Ringdal concedes that he has not weighted various family or prostitution archetypes against one another. To me this seems a missed opportunity. A focal point are the Victorians and Ringdal works to the "basic assumption underlying [his] text [...] that the Victorians are still among us - clad in postmodernism" (p4). Thus, he is critical of nineteenth century evolutionist theory which linked the development of humankind and prostitution to the development of monetary economies and class divisions on the basis of a natural promiscuity. Engels' prediction that women in a brave new communist world would break free of all chains and recapture a virtuous life lets Ringdal conclude that Engels' himself is revealed as a Victorian. Indeed, as one is always situated within particular socio-political and cultural contexts it would be futile to negate that Engels was a Victorian and that early sexologists, such as Iwan 
Bloch who wrote the first reflexive history of prostitution, was also embedded in the proliferating discourses on sexuality of the nineteenth century ${ }^{2}$.

Problematic in his approach is the fleeting criticism of other approaches without looking at the in more detail. Indeed, the attention to detail must be a grindstone for everybody interested in historiography rather than history. Over 430 pages there is only one definition of prostitution (defined as sex for money or its equivalent) (p.5) yet the book wavers between providing a history of prostitutes and a history of prostitution. This is no small detail and need not be entirely contradictory but ought to have provoked the writer to reflect more on the links between the two concepts. Using a variety of sources such as historical and medical studies, memoirs, biographies and handbooks the book presents histories of periods and particular socio-political contexts, cultural histories (such as the literature on prostitution in 18C), and so on could make for a textured analysis but for the academic reader the absence of references in the text and the referral to the end of the book to find quotes and references is certainly frustrating.

Despite his solidarity with prostitutes which underpin his point of view and the sociopolitical project emerging in the last few chapters it does little to do that in large parts of the book. His aim to provide an academic as well as popular book takes some doing and it is not helped by unfortunate translations in parts. Ringdal's journalist background comes through on several occasions where sensationalising is going on. For an academic book, it provides a historical overview of selected regions and cultural and political contexts and its merit is in introducing particular time periods. The claim to be a global history remains unfulfilled and looks more like an effort not to be exclusively a Western history. The many interesting and fascinating accounts, facts and descriptions of the book can provide a starting point, as well as the bibliography, for a scholarly investigation of a historiography of prostitution. For those exclusively interested in descriptive histories the book may be more satisfying. It is unfocused and unstructured at times, jumping between regions and historical periods and sources without rationale. There is little commentary of descriptive textual passages that qualify the meanings of particular sexual practices, people's positions or wider socio-cultural contexts. To some extent this is also more a history of reflections on prostitutes rather than a history of prostitution which, in my view, would warrant more critical engagement with key concepts. Thus it has the character of a moral cartography which contains interesting parts but the temporal and geographical disorderliness towards the end of the book makes the material considered appear eclectic.

The book starts out with Babylonian history of prostitution where prostitution "in its first and Western variety" is claimed to have come into existence in and around Mesopotamian temples, which were the centre of social, political and spiritual life. The second chapter consists of biblical stories about gender and sexuality before chapter three looks in more detail at "fallen angels" in the Old Testament. Chapter four travels to Greece BC where the earliest forms of the sex industry can be found

\footnotetext{
${ }^{2}$ There are many of histories of prostitution and classic accounts from contemporary social historians are, for example, Vern and Bonnie Bullough (1983) Women and Prostitution or Vern Bullough (1964) The History of Prostitution.
} 
which developed in tandem with Western democracy. Porneia, "houses where people went naked" and filled with purchased slave women and girls, had been created in 6 B.C. which were the first well-organised and state-supervised prostitution trade disentangled from the religious and ritual boundaries that had marked the sale of sex in earlier periods. Typologies of prostitutes were discernible in Babylonian times but became more clear during Greek liberalism where distinctions were made between deichtrides (women of humble means on display in porneia), auletrides (free women with artistic skills and accomplishments) and heterae, or "companions" who were free agents and property owners and thus the top stratum of Greek prostitutes. Chapter five undertakes to provide a history of prostitution within Hinduism which was characterised by ambiguity. Seen as members of society it was considered a good omen to meet a prostitute in the street while it was a bad omen to meet a widow. Hindu culture was thus distinguished by great sexual freedom combined with an ambiguous view of the female sex. Chapter six takes the reader to Rome which places prostitution within prevalent Roman ethics and a moral code which separated sex and love consecrating the family for procreation and prostitution, meant to take place outside the city walls, for sex. The New Testament is discussed in chapter seven with Mary Magdalene receiving focal attention. Chapter eight takes us briefly to China and the story of a girl named Yü Hsüan-chi before the next chapter broaches "Muhammad's women" through sources in the Qu'ran. Ten goes to medieval Europe and it "guilds, cloisters, rogues and rapists" and gives some attention to discourses around women travelling and bathhouses as locations of prostitution.

An acknowledgement of not just the existence of prostitution but the status of prostitution if the Federation of Parisian Harlots, the city's guild of prostitutes which in 1474 had four thousand members. Rules around prostitution are discussed for the first time in terms of condemned sexual practices and relations, including anal and oral sex, or sexual relations between different religions as well as rules on age (thus in 1403 Florence men over 30 were forbidden to visit brothels in an attempt to force them into matrimony). Eleven takes up the figure of the "repentant whore" and Renaissance writers approach to Mary Magdalene. Twelve delves into the war of the roses, based on the book The Romance of the Rose which promoted promiscuous love and visits to prostitutes, and Christine de Pizan's writings in retaliation. Venereal diseases make an appearance and the Reformation and Counter-reformation which cast prostitution as a state of ill repute during the sixteenth century and the European history takes a break with the splendour and misery of the courtesans. A jump to "love in the South Seas" considers the impact of colonialism along the Pacific while chapter sixteen looks at English literature through Fanny Hill: The Memoirs of a Woman of Pleasure and other literature from the $18^{\text {th }}$ Century. From the basis of the opera Madam Butterfly Japanese traditions around sex for sale are then examined and then Africa's history of prostitution is dedicated one chapter. Then 19C France is discussed through literature and paintings before arriving at the "moral crusaders" and the prominent figure of Josephine Butler. Sex in the Wild West which charts North American history of prostitution begins with the settlers and ends with Hollywood films' portrayal of prostitution. A chapter on Imperialist prostitution from an English perspective is followed by a short excursion to Latin America yet hardly representative as it only picks up on connotations with the tango. A very brief Ottoman footnote focuses on Constantinople's history, eunuchs and harems before 25 picks up the white slave trade again in a world wide context. WWII then forms a periodic context for the next chapter with a special focus on Japan and the recently 
emerging stories of "comfort women" which constituted a form of non-voluntary prostitution during the war years. Then 1980s US context is illuminated and the emergence of political activism by sex workers. Sex tourism curiously is discussed in the context of academic research by women ethnographers who had "gone native" for their research on sex work before 29 pitches feminism against the sex workers' movement which only relies on Kate Millet's tradition of anti-pornography and antiprostitution feminism. Migration, drugs and HIV all come together in this last chapter as well resulting in a rather unfocused ending.

The book is reminiscent of other identity based histories, that is, the claiming of an identity throughout history without contextualising or problematising the use of that category. Thus, rather than a history of prostitution which would warrant a look at those providing sex, those buying or accessing sex, those inside and outside the "sex industry" and their relationships in a larger context, this is a history of women prostitutes with some amendments that men were also throughout history providing sexual services. Interlinking these more closely could have produced a book which says more about hierarchies of gender relations including "intra-gender" relations.

Ringdal rarely questions the usefulness of the concept of prostitution such as in ancient Rome whose central institution was slavery which thus casts "certain problems with the general use of the term prostitution". Harlots, prostitutes, whores originating from the Greek hora, many metonyms/metaphor throughout time such as bedroom upholstery, parish worker, dice, sparrow, sunbeam, flower girl (in Greek times). Sanskrit has seen a proliferation of words for prostitutes in last century B.C.: ganika were luxury prostitutes, devandasi temple prostitutes, vecya "cheap sex worker tempting men with her dress" and so forth. In rome a meretix was a "woman who earns money" and was a free and locally born woman who engaged in part-time prostitution. Interestingly, she had to wear a man's toga but was denied the use of colour purple and had to wear her hair down. Prostitute is Roman in origin literally referring to exposure of the genitalia.

By contrast, Outspoken Women and Modern Love both cast a much more specific time and map out different aims for their historical analyses of modernity, sexuality, intimacy and gender relations. Modern Love seeks to cast an intimate history of men and women in twentieth century Britain using a variety of sources but threading this history conceptually around ideas and practices of "mutuality" in heterosexual emotional and sexual relationships. Having conducted two years of laborious research on mixed youth clubs ${ }^{3}$, marital problems and pornography Collins weaves these social histories together by examining the claims laid to sexual politics by early social and sexual reformers such as Carpenter, Stopes or Ellis. In what follows in the book, Collins uses the idea of mutuality proposed by modern sex reformers and assesses the rise and fall of "mutuality" which he understands as a theory about how modern heterosexual relationships should work. Thus not concerned with sexual practices per se but with ideas what heterosexual practices should ideally be embedded in regarding their emotional and social context, Collins does not so much provide a history of intimacy - in as much as he does not seek to explore manifestations of intimacy - but rather the history of a concept. The book is structured around the argument of the

\footnotetext{
${ }^{3}$ The ways in which young people are always a focus in relation to sexuality and nation has been discussed by Matthew Waites, The Age of Consent: Young People, Sexuality, and Citizenship (Palgrave, 2005) but also Natalia Gerodetti, Modernising Sexualities (Peter Lang, 2005).
} 
conception of mutuality in the era of the sex reformers, the pinnacle of mutuality in the 1960 s and the decline of mutuality through increased individualisation.

Although other historians ${ }^{4}$ have examined the history of sexuality in this time period, Collins, by contrast, casts a close look at the ideas and practices of the social and emotional expectations mapped onto heterosexual relationships. Beginning with the proliferation of discourses around meanings and expectations of heterosexual relationships Collins explores the strain between those who argued that women and men should seek a greater mutual respect in marriage and those who believed that men and women's interests and desires were irreconcilable and their psychology so different that mutuality was a mere illusion. Collins charts the fortunes of mutuality through a series of case studies such as mid-century youth clubs and marriage counselling, the rise of soft porn in the 1960s, the women's liberation movements from the 1970s ending with an epilogue on the effects of individualisation in the 1990s. Collins outlines how the idea of mutuality rose during the interwar years as companionate marriages came to be seen as something good and achievable, even though in practice few people knew how to negotiate it and his records consulted point to a certain class bias. According to Collins' argument, mutuality reached its pinnacle in the 1960s, against the backdrop of new contraceptive methods such as the pill and, somewhat surprisingly, the rise of soft porn industry. Although the pill removed the threat of pregnancy it put new strains on relationships. Sexual permissiveness which has come to characterise the 1960s has also taken the concept of mutuality, according to Collins, into soft pornography which presented a new rhetoric of a feminine ideal as women having the same sexual desires as men.

Leaving a discussion of the revolutionary potential of pornography aside, it seems nevertheless somewhat problematic to chart pornography as a site of mutuality given the power differentials of those involved which is not to say that pornographers would not self-servingly instrumentalise an idea of "mutuality". This is not least problematic because Collins continually charts feminist demands about equality and the reduction of women's dependence on men in opposition to ideas of mutuality and makes feminists responsible for this opposition. In pursuing this argument he makes, however, little distinction between different feminist positions whilst clearly talking about radical feminists only who advocated independence and separate spheres from men. Similarly, feminist demands for changes in all aspects of society, including culture, economy, politics, sexual politics and family relations could be seen as a quest for equality, rather than refusal and dismantling of mutuality. Clearly, the concept of "equality" has always had a stronger foothold on feminist politics than "mutuality" yet this s not brought into the equation much by Collins. Simultaneously, the voices of men around mutuality in principle and practice seem to have got lost somewhat. Yet Collins holds individualism rather than feminism responsible for the decline of mutuality in relationships. However, his treatise of a rising individualism is relegated to an epilogue which covers 1990 to 2000 and which surprisingly, leaves out any mentioning of mutuality or "pure love" in gay and lesbian relationships which

\footnotetext{
${ }^{4}$ See for instance, Jeffrey Weeks, Making Sexual History (Polity, 2000); Hera Cook, The Long Sexual Revolution : English Women, Sex, and Contraception, 1800-1975 (Oxford, 2004); Lucy Bland, Banishing the Beast : English Feminism and Sexual Morality 1885-1914 (Penguin, 1995); Jane Lewis, The End of Marriage?: Individualism and Intimate Relations (Elgar publication, 2001) or Lesley Hall Sex Gender and Social Change in Britain since 1880 (Macmillan, 2000).
} 
sociologists ${ }^{5}$ have come to see as influential of heterosexual relationships. Thus whilst Collins provides an important source book of intimacy in relation to the particular concept of "mutuality", some complexities as well as other dimensions of intimacy are cast aside to further the argument of the conception, rise and fall of intimacy rendering the first half o the book the much more succinct and fascinating.

In Outspoken Women Lesley Hall takes a different approach to similar concerns as Marcus Collins by considering twentieth century ideas and politics on marriage, desire and pleasure, birth control and sexual knowledge and sex education. In addition to these areas which could be seen as overlapping Hall also considers same sex relationships, celibacy and singleness as well as prostitution and sexually transmitted infections spanning the hundred years from 1870 to 1969 . Differently to Collins, however, Hall looks at these issues in various periods by providing an anthology of women's writing about sex. In doing so, Hall provides the sources and materials hitherto neglected by a history of sexology which has relied on the respectable scientific credentials of medical or legal writings which have largely been written by male professionals. In addition, Hall also provides a different rationale to her anthology which is to question, once again, the originality of some of the 1960s and 1970s debates about sexuality, sexual politics and family arrangements by providing accounts of key British women writers who have articulated demands on sexual freedom, desire, pleasure, marital satisfaction and so on throughout the hundred years preceding second wave feminism.

Hall undertakes this project by presenting excerpts of writings of a variety of women demonstrating the diverse positions taken by women in the late nineteenth century and throughout the twentieth century which include various reformers. The reader looking for extensive discussion and analysis of the material will have to wait for a potential follow up book as Outspoken Women is a selection of writings from various genres with only a few pointers presuming a reader who is familiar with the rough contours of sexual histories and one looking for primary material without having to travel to archives. Hall presents us with important and hitherto neglected source materials. By presenting extracts from books and pamphlets as well as essays and articles Hall makes an implicit epistemological critique of what has been validated as knowledge for the history of sexuality yet at the same time she does not go as far as including other genres which she deems to be part of a genealogy of sexuality such as polemic literature, religious discourse, works of popular instruction, essays, social surveys or fiction. Including these would interestingly bridge the boundaries between social and cultural histories further.

\footnotetext{
${ }^{5}$ Anthony Giddens, The Transformation of Intimacy: Sexuality, Love and Eroticism in Modern Societies (Polity, 1992); Lynn Jamieson, Intimacy: Personal Relationships in Modern Societies (Polity, 1998) or Carol Smart and Bren Neale, Family Fragments? (Polity, 1999).
} 